\title{
KOMUNITAS BELAJAR MAHASISWA SEMESTER III PROGRAM STUDI PENDIDIKAN BAHASA DAN SASTRA INDONESIA DALAM PEMBELAJARAN KETERAMPILAN MEMBACA MELALUI KEGIATAN LESSON STUDY
}

\author{
Nur Mei Ningsih *)
}

\begin{abstract}
To improve process of eduacation quality needs inovation that should be done continuously. One of those inovations is by changing the learning paradigm from teacher centered to student centered. So, from this learning is not only focus on students but also how the teacher teaches. One of improvement models to improve the teacher is through lesson study. Lesson study is a creation model of teacher profession collaboratively and continously, based on collegiality principle that helps each others in learning to build learning community (democartics, openness, and continue). Learning community at the third semester students of STKIP Muhammadiyah is quite good, it looks during learning process of reading subject, they look active, and also they are entusistics to understand the material given. It is done with the member of their group, they can also discuss with another group, but it was found that there are three students who have different attitude with another. It was also one student from second group that did not have motivation during learning process, he is A, and from first group is B, and from third group is Lilik, but the lecturer always guided them because they lack of motivation and interest during discussion, it based on the observation from observers, finnaly it can give suggestion for the lecturer to be better in teaching reading.
\end{abstract}

Key words: lesson study, learning community

\section{PENDAHULUAN}

Pembelajaran adalah kegiatan yang dilakukan oleh pengajar/dosen dan pembelajar/mahasiswa untuk mencapai kompetensi yang diharapkan. Dalam proses pembelajaran tentunya melibatkan dua unsur yang tidak terpisahkan yaitu antara pendidik /pengajar dan pembelajar/mahasiswa (Priyatni, 2014:270).

Upaya peningkatan mutu pendidikan melalui perbaikan proses pembelajaran merupakan inovasi yang terus dilakukan. Salah satu inovasi tersebut adalah mengubah paradigma pembelajaran dari pembelajaran yang berpusat pada pengajar/dosen menjadi pembelajaran yang berpusat pada pembelajar/mahasiswa. Jadi dalam pembelajaran ini bukan hanya terfokus pada pembelajar/mahasiswa belajar, tetapi juga bagaimana pengajar/dosen mengajar. Pada kenyataanya pendekatan pembelajaran yang dilakukan di perguruan tinggi selama ini berpusat pada pengajar/dosen atau berbasis mengajar, artinya bahwa selama proses pembelajaran pengajar/dosen lebih banyak memberi materi yang berupa pengetahuan. Pembelajar/mahasiswa diharapkan dapat menguasai konsep/pengetahuan yang 
diberikan oleh pengajar/dosen dalam keterampilan belajar dan inovasi, dan pembelajaran. Dosen lebih banyak terampil memanfaatkan informasi, media, mendominasi pembicaraan, sementara mahasiswa hanya sebagai wadah yang akan diberi informasi pengetahuan, tanpa memberikan hak-haknya kepada mahasiswa sebagai pembelajar. Berbeda pada kondisi sekarang ini pembelajaran tidak lagi bersifat konvensional yang lebih menekankan pada pengajarnya, tetapi diubah menjadi berpusat pada pembelajar/mahasiswa atau berbasis belajar. Adapun ciri utama dalam pembelajaran berbasis belajar supaya terbangunnya kemandirian siswa untuk membangun pengetahuan dan ketrampilan di dalam dirinya sendiri dari berbagai variasi informasi melalui interaksi dalam pembelajaran.

Dalam proses pembelajaran saat ini pembelajar/mahasiswa dikondisikan aktif sehingga pusat pembelajaran bertumpu kepada pembelajar (student centered). Kedudukan pembelajaran dalam pembelajaran Abad 21 juga digambarkan dalam sistem yang dikembangkan. Dalam pembelajaran Abad 21 menurut kerangka pembelajaan, elemen-elemen saling mendukung (standar dan penilaian, kurikulum dan pelajaran, pengembangan profesi, pengembangan profesional, dan lingkungah belajar) harus mampu membantu pembelajar mencapai kompetensi. teknologi (literasi informasi, literasi media, dan literiasi ICT). Target kompetensi pembelajar yang kompleks tersebut menjadi tanggung jawab Lembaga Pendidikan Tinggi yang dilaksanakan para dosen dalam melaksanakan pembelajaran atau perkuliahan. Untuk dapat mencapai kompetensi tersebut, maka diperlukan modelmodel pembelajaran didalamnya menempatkan pembelajaran berproses. Model pembelajaran yang digunakan dalam proses pembelajaran sangat bervariasi bergantung pada materi apa yang akan diberikan oleh pengajar/dosen kepada pembelajar/mahasiswa. Upaya perbaikan pembelajaran bukan hanya melihat dari sisi pembelajar/mahasiswa saja tetapi juga mengupayakan supaya pengajar/dosen dapat meningkatkan kualitas dalam pembelajaran. Salah satu model pembinaan dan pengembangan untuk meningkatkan kualitas tenaga pengajar/dosen adalah melalui model lesson study.

Lesson study dikembangkan pertama sekali di Jepang yang dilaksanakan sebagai program pengembangan pengajar/dosen. Lesson study dipercaya berhasil meningkatkan praktik pembelajaran. Lesson Study merupakan suatu model pembinaan profesi pendidik melalui pengkajian Kompetensi yang diharapkan dalam aspek: pembelajaran secara kolaboratif dan kehidupan dan karir keterampilan, berkelanjutan, berdasarkan prinsip-prinsip 
kolegialitas yang saling membantu dalam pembelajaran untuk membangun komunitas belajar (demokratisasi, keterbukaan, dan berkelanjutan).

Lesson Study mulai dikenal di Jepang pada tahun 1900-an, sebuah metode analisis kasus pada proses pembelajaran ditujukan untuk membantu pengembangan profesional para pengajar/dosen dan membuka kesempatan bagi mereka untuk saling belajar berdasarkan praktik-praktik nyata ditingkat kelas (Rusman, 2010:287). Adapun manfaat dari lesson study adalah pengajar/dosen dapat mendokumentasikan kemajuan kinerjanya, pengajar/dosen dapat memperoleh feeds back dari teman sejawatnya, dan pengajar/dosen dapat mempublikasikan hasil akhir dari lesson study yang telah dilakukan.

Menurut Hendayana, (2007:10) Lesson study merupakan model pembinaan profesi pendidik melalui pengkajian pembelajaran secara kolaboratif dan berkelanjutan berlandaskan prinsip-prinsip kolegalitas dan mutual learning untuk membangun komunitas belajar. Lesson study bukan merupakan metode atau strategi pembelajaran tetapi merupakan suatu kegiatan. Lesson study dapat menerapkan berbagai metode ataupun strategi pembelajaran yang sesuai dengan situasi, kondisi, dan permasalahan yang dihadapi pendidik. Lewis dan Murata (2006) dalam Susilo dkk (2011:3) dalam melaksanakan Lesson study pengajar/dosen secara kolaboratif (1) mempelajari kurikulum dan merumuskan tujuan pembelajaran dan tujuan pengembangan peserta didiknya (mengembangkan kecakapan hidupnya, (2) merancang pembelajaran untuk mencapai tujuan, (3) melaksanakan dan mengamati suatu research lesson dan, (4) melakukan refleksi untuk mendiskusikan pembelajaran berikutnya. Menurut Slamet (2010:59) Lesson Study merupakan kegiatan terus menerus yang tiada henti dan suatu upaya untuk mengaplikasikan prinsip-prinsip dalam Total Quality Management, yakni memperbaiki proses dan hasil pembelajaran siswa secara terus-menerus, berdasarkan data. Lesson Study merupakan kegiatan yang dapat mendorong terbentuknya sebuah komunitas belajar (Learning society) yang secara konsisten dan sistematis melakukan perbaikan diri (Saito, 2015:58). lesson study adalah suatu pendekatan peningkatan kualitas pembelajaran yang dilaksanakan oleh dosen secara kolaboratif, dengan langkah-langkah pokok merancang pembelajaran untuk mencapai tujuan, melaksanakan pembelajaran, mengamati pelaksanaan pembelajaran, serta melakukan refleksi untuk mendiskusikan pembelajaran yang dikaji untuk bahan penyempurnaan dalam rancangan pmbelajaran berikutnya.

Target dari Lesson study adalah membentuk learning comunity (komunitas belajar) yang memiliki tiga filosofi, yaitu: filosofi demokratisasi, terbuka dan berkelanjutan. Filosofi demokratisasi berarti 
bahwa setiap peserta didik harus mendapatkan hak belajarnya sesuai tingkat kemampuannya. Siswa saling belajar dan dosen juga tetap mau belajar, tidak hanya mahasiswa yang selalu mendengarkan dosen, tetapi guru juga siap untuk mendengarkan pendapat mahasiswa, tidak hanya dosen yang minta dihargai dan dihormati, tetapi dosen juga menghargai setiap individu mahasiswa serta setiap mahasiswa mendapatkan pelayanan dan kesempatan belajar yang memadai.

Filosofi terbuka artinya pembelajaran di kelas tidak menjadi hak otoritas dosen secara mutlak. Pembelajaran di kelas yang dilakukan oleh dosen terbuka untuk setiap orang yang peduli terhadap pendidikan. Dosen bersedia membuka kelasnya untuk dilihat oleh teman sejawat, Kepala Sekolah/pimpina, Pengawas sekolah, orang tua mahasiswa, mahasiswa calon dosen yang sedang belajar, bahkan terbuka untuk masyarakat. Selain itu, atas kesadarannya dosen terbuka terhadap masukan dan saran serta selalu mau dan mampu untuk melakukan perubahan dan perbaikan dalam menjalankan profesinya.

Filosofi berkelanjutan, berarti bahwa dosen selalu melakukan perbaikan untuk meningkatkan proses dan hasil pembelajaran secara terus-menerus, selalu berupaya memenuhi hak-hak belajar mahasiswanya, memperhatikan perkembangan setiap mahasiswanya dan selalu meningkatkan prestasi mahasiswanya sesuai dengan minat dan kemampuan masing-masing mahasiswa. Secara garis besar filosofi ini mengandung makna bahwa kualitas pendidik dan peserta didik selalu berubah dan berkembang secara berkelanjutan sehingga nantinya dihasilkan SDM yang berdaya saing tinggi (Makalah, Pelatihan PEKERTI. 2017).

Sukirman (2006) memandang lesson study sebagai model pembinaan profesi pendidik melalui pengkajian pembelajaran secara kolaboratif dan berkelanjutan berdasarkan prinsip-prinsip kolegalitas mutual learning untuk membangun learning community. Dengan demikian lesson study bukan suatu metode pembelajaran atau strategi pembelajaran. Namun demikian dalam suatu kegiatan lesson study dapat digunakan berbagai metode, pendekatan, strategi pembelajaran sesui dengan situasi dan kondisi dan permasalahan yang dihadapi. Melalui pembinaan profesi ini pengajar dapat meningkatkan kualitas dalam pembelajaran terutama dalam pembelajaran mata kuliah Keterampilan Membaca (Pelatihan PEKERTI. 2017)

Mata kuliah Keterampilan Membaca diberikan kepada mahasiswa semester III program Studi Pendidikan Bahasa dan Sastra Indonesia di Sekolah Tinggi Keguruan dan Ilmu Pendidikan (STKIP) Muhammadiyah Kotabumi Lampung. Dosen mata kuliah keterampilan membaca termasuk dosen binaan dalam kegiatan lesson study. 
KegiatanLesson study dalam mata kuliah keterampilan membaca dilakasnakan dalam tiga tahapan yang mencakup plan (merencanakan), Do (melaksanakan), dan See (refleksi) dalam mata kuliah keterampilan membaca. Melalui kegitan lesson study, pengajar/dosen mampu meningkatkan mutu/kualitas kinerjanya dan mahasiswa dapat meningkatkan kualitas belajarnya melalui proses pembelajaran. Mata kuliah keterampilan membaca yang diberikan pada mahasiswa semester III, bertujuan untuk meningkatkan kemampuan mahasiswa dalam menguasai konsep serta mampu mempraktikan berbagai jenis membaca dalam kehidupan sehari-hari.

Gambaran pelaksanaan lesson study meliputi kegiatan plan, do dan see, yang secara garis besar dapat dikemukakan sebagai berikut:

1) Melakukan perencanaan dengan mempertimbangkan tujuan pembelajaran dan karakteristik serta perkembangan siswa/mahasiswa.

2) Melaksanakan pembelajaran dan melakukan observasi untuk mengumpulkan data tentang aktivitas belajar siswa dan perkembangannya.

3) Menggunakan data hasil observasi untuk melakukan refleksi tentang pembelajaran secara mendalam dan lebih luas.

4) Jika diperlukan, dilakukan perencanaan ulang dengan topik yang sama untuk melakukan lesson study pada kelas berbeda (Pelatihan PEKERTI. 2017)

\section{Langkah-langkah Lesson Study}

Menurut Susilo (2011:35) Lesson study di Indonesia meliputi 3 tahap: tahap Perencanaan (Plan), tahap pelaksanaan (Do), tahap pengamatan dan refleksi (See). Siklus pengkajian pembelajaran dilaksanakan dalam tiga tahap,

\section{1) Perencanan (Plan)}

Tahap perencanaan (Plan), tahap perencanaan ini sekelompok pengajar/dosen secara bersama-sama (kolaboratif) menyusun rencana pembelajaran semester (RPS) dengan semua perangkat pembelajaran yang diperlukan (LKM, Instrumen untuk evaluasi, media, serta perangkat pembelajaran lainnya). Tahap perencanaan ini, setiap dosen anggota kelompok Lesson Study mencurahkan pikiran untuk menghasilkan skenario pembelajaran yang baik atau dengan strategi yang tepat dan operasional (sesuai dengan kondisi dan sistuasi siswa, sekolah dan sarana pendukungnya,). Perencanaan dilakukan secara kolaboratif berdasarkan permasalahan di kelas untuk mengembangan model pembelajaran yang berpusat pada mahasiswa.

2) Pelaksanaan (Do) 
Tahap pelaksanaan (Do), dimaksudkan untuk menerapkan rancangan pembelajaran yang telah direncanakan. Dalam tahap Do seorang “dosen model” melakukan pembelajaran di kelas. Anggota kelompok melakukan observasi (terhadap aktivitas belajar semua mahasiswa atau sesuai dengan tugas masing-masing). Setiap observer mencatat hasil observasi sebagai bahan refleksi, jika mungkin dianjurkan untuk merekam kegiatan pembelajaran dengan handycam. Pada tahap mengobservasi ini, setiap observer tidak boleh mengintervensi atau mengganggu mahasiswa dalam proses pembelajaran. Harapannya adalah pembelajaran terjadi secara alami.

\section{3) Refleksi (See)}

Kegiatan refleksi dilakukan setelah kegiatan pembelajaran (do) selesai dilaksanakan, untuk melihat berbagai hal yang ditemukan dalam pelaksanaan pembelajaran, baik oleh dosen model maupun para observer. Pengajar/dosen dan para observer melakukan sharing atas temuannya berkaitan dengan aktivitas belajar mahasiswa selama proses pembelajaran. Observer dan dosen model saling belajar dari pembelajaran yang telah diamati dan hasil sharing digunakan untuk merivisi rencana pembelajaran. Tahap pengamatan dan refleksi (See) dimaksudkan untuk menemukan kelebihan dan kekurangan pelaksanaan pembelajaran. Pada tahapan ini dilakukan diskusi secara formal (dipimpin oleh moderator dan disertai notulis). Dosen model (pengajar) diberi kesempatan pertama untuk melakukan refleksi diri, tentang: perasaan dosen model sebelum, saat, dan setelah melaksanaan pembelajaran (open class); alur skenario atau langkah pembelajaran yang berhasil dan tidak berhasil dilaksanakan; Penilaian terhadap keberhasilan pembelajaran yang dilakukan.

\section{METODE}

Metode yang digunakan adalah metode kualitatif dalam latar yang wajar (natural) dengan berupaya memahami dari apa yang diamati (Sentana, 2010:45). Metode ini juga disebut metode artistik (Sugiyono, 2011:7) karena proses bersifat seni (kurang terpola) dan disebut metode interpretative karena hasil berkenaan dengan interpretasi data yang dikumpulkan di lapangan. Metode yang digunakan dalam penyusunan artikel berdasarkan pengamatan langsung oleh dosen model dalam pelaksanaan pembelajaran keterampilan membaca. Dosen model mendiskripksikan mengenai pelaksanaan pembelajaran yang dilaksanakan pada mahasiswa semester III STKIP Muhammadiyah Koabumi. 
III. HASIL DAN PEMBAHASAN

\section{Plan (Merencanakan)}

Tahap perencanaan (Plan), pada tahap perencanaan ini dosen model bersama dosen lain tim Lesson Study Program Studi Pendidikan Bahasa dan Sastra Indonesia secara kolaboratif menyusun Perangkat Pembelajaran Semester mata kuliah keterampilan membaca (RPS, LKM, Instrumen untuk evaluasi, media, serta perangkat pembelajaran lainnya). Tahap perencanaan ini, dosen model bersama anggota kelompok Lesson Study mencurahkan pikiran dalam menghasilkan skenario pembelajaran yang baik atau dengan strategi yang tepat dan operasional (sesuai dengan kondisi dan sistuasi mahasiswa serta sarana pendukungnya). Pada saat penyusunan Perencanaan Pembelajaran Semester/lesson designe banyak masukan yang diberikan oleh dosen tim lesson study Program Studi Pendidikan Bahasa dan Sastra Indonesia terkait dengan mata kuliah Keterampilan Membaca, begitupula dalam penyusunan LKM, instrument penilaian sampai dengan penggunaan media dalam pembelajaran. Perencanaan pembelajaran yang disusun dilakukan secara kolaboratif berdasarkan permasalahan di kelas untuk mengembangan model pembelajaran yang berpusat pada mahasiswa. RPS yang dibuat dengan pokok materi Pengembangan Sikap Kritis dalam membaca menggunakan model pembelajaran Snoball Trowing.
Pada tahap Plan, dosen model memaparkan langkah-langkah pembelajaran menggunakan model snowball trowing dihadapan para obsever/pengamat. Adapun langkah-langkah yang harus dilakukan oleh mahasiswa dan dosen dalam pembelajaran keterampi lan membaca adalah (1)mahasiswa membentuk kelompok 4-5 orang; (2)membaca materi yang baru saja dibahas (3) mahasiswa menyusun/ membuat pertanyaan; (4)mahasiswa menggulung kertas/membuat seperti bola yang berisi pertanyaan, lalu dilemparkan kepada kelompok lain; (5)mahasiswa yang mendapatkan gulungan kertas/membuat seperti bola yang berisi pertanyaan, maka kelompok tersebut yang harus menjawab pertanyaan secara bergantian; (6) mahasiswa diminta untuk menyimpulkan inti materi yang didiskusikan. Setelah itu dosen model juga memaparkan instrument yang digunakan dalam pembelajaran keterampilan membaca. Instrument yang disusun berupa tes tertulis (mahasiswa membuat pertanyaan berdasarkan materi yang dibahas sebanyak lima pertanyaan/soal) dan secara lisan mahasiswa menjawab pertanyaan yang sudah dibuat oleh kelompok lain. Melalui pemaparan lesson desagne mata kuliah keterampilan membaca selesai dan tidak ada komentar dari para observer, lalu dosen model melaksanakan Do (pelaksanaan). Dari penjelasan tersebut terlihat bahwa pada kegiatan plan, dosen model bersama dosen 
prodi tim Lesson Study bekerjasama dan terbuka dalam menyusun Rencana Pembelajaran Semester, LKM, dan instrument penilaian. Keterbukaan maksudnya dosen model siap menerima saran atau masukan dari dosen prodi/prodi lain tim lesson study dalam penyusuna Rencana Pembelajaran Semester, LKM, dan instrument penilaian. Selain itu bersifat demokratis, artinya bahwa dalam menyusun RPS, LKM, dan instrument penilaian pun dilakukan secara bersama antara dosen model dengan dosen prodi tim lesson study. Hal ini terlihat dari masukan dan saran yang diberikan oleh dosen prodi tim lesson study.

\section{Pelaksanaan (Do)}

Tahap pelaksanaan $(D o)$, dosen model menerapkan rancangan pembelajaran semester/lesson designe yang telah direncanakan. Dalam tahap Do seorang “dosen model" melakukan pembelajaran di kelas. Anggota kelompok tim lesson study melakukan observasi (terhadap aktivitas belajar semua mahasiswa atau sesuai dengan tugas masing-masing). Dalam proses pembelajaran mata kuliah keterampilan membaca dengan bobot 3 SKS dan waktu 150 menit, dosen model mengawali dengan memaparkan langkah-langkah yang harus dilakukan oleh mahasiswa dan dosen dalam proses pembelajaran.

\section{A). Langkah-langkah dalam melaksanakan proses pembelajaran mata kuliah keterampilan membaca:}

Pertama yang dilakukan oleh dosen model dalam pembelajaran adalah

(a) menjelaskan materi Pengembangan Sikap Kritis dalam Membaca;

(b) membagi kelompok dan mengelompokan mahasiswa;

(c) meminta ketua kelompok untuk memberi penjelasan kembali kepada anggota kelompok dari apa yang sudah didapat dari dosen model;

(d) meminta mahasiswa dalam kelompok membuat/menyusun pertanyaan sesuai dengan materi yang sudah dijelaskan oleh dosen model;

(e) meminta beberapa mahasiswa untuk menyimpulkan materi yang sudah didiskusikan.

Kedua dalam proses pembelajaran yang harus dilakukan oleh mahasiswa adalah

(a) mahasiswa mengamati, membaca, mendengarkan penjelasan dari dosen terkait materi Pengembangan Sikap Kritis dalam Membaca.

(b) mahasiswa berkelompok dan ketua kelompok menjelaskan kembali mengenai materi yang sudah dijelaskan oleh dosen model;

(c) mahasiswa dalam kelompok saling bekerjasama antarmahasiswa satu dengan mahasiswa lain dalam kelompok 
atau kelomok satu dengan kelompok lain mengenai materi yang belum dimengerti

(d) mahasiswa bertanya dan menanggapi dalam kelompok

(e) mempresentasikan hasil yang sudah didiskusikan dalam kelompok

(f) kelompok lain bertanya dan menangapi

\section{B). Pelaksanaan Pembelajaran Mata Kuliah Keterampilan Membaca}

Berawal dari pemberian materi mengenai definisi membaca kritis dan langkah-langkah dalam membaca kritis, lalu dosen model memberi kesempatan kepada mahasiswa untuk bertanya apa yang sudah didapat melalui penjelasan materi tersebut. Beberapa mahasiswa bertanya mengenai materi yang dijelaskan diantaranya adalah mahasiswa yang bernama C. Pertanyaannya apa sajakah yang harus dilkakukan oleh pembaca dalam mengembangkan sikap kritisdalam membaca lalu dosen model memberi kesempatan terlebih dahulu kepada mahasiswa dalam kelompok lain untuk menananggapi pertanyaan dari Riswansyah. Kelompok lainpun (kelompok 5) menanggapi pertanyaan mahasiswa tersebut dengan memberikan jawaban sesuai dengan yang ditanyakan, sementara kelompok D (kelompok 1) menanbahkan jawaban yang sudah dikemukakan oleh kelompok 5. Selain itu kelompok 2 (kelompok si E) menambahkan jawaban yang dikemukakan oleh (kelompok).
Selanjutnya dosen model tetap memberi kesempatan kepada mahasiswa lain untuk mengajukan pertanyaan ataupun menanggai, tetapi mahasiswa lain belum tergerak untuk mengajukan pertanyaan ataupun menanggapi. Demokratisasi melalui proses pembelajaran tersebut terlihat pada saat dosen memberikan hak belajarnya kepada mahasiswa untuk bertanya, menanggapi, mengemukakan ide/gagasan dan memberikan saran terkait dengan proses pembelajaran, hal ini bukan saja mahasiswa dan dosen, tetapi keterbukaan dapat dilihat pada mahasiswa satu dengan mahasiswa lain saling menanggapi atau menambahkan jawaban yang diberikan, sehingga proses pembelajaran semakin menarik untuk diikuti. Melalui kegiatan pembelajaran seperti yang diungkapkan tersebut, terlihat proses pembelajaran lebih memfokuskan pada pembelajar/mahasiswa untuk menemukan konsep materi yang dipelajari melalui kegiatan pembelajaran. Setelah penjelasan materi secara singkat dari dosen model, lalu mahasiswa diminta untuk berkelompok mendiskusikan materi yang dibahas.

\section{C). Pelakasanaan Kegiatan Diskusi Kelompok}

Mahasiswa berkelompok untuk mendiskusikan materi yang sudah dijelaskan, dalam diskusi ketua kelompok dan anggota secara bersama-sama menemukan inti atau konsep materi yang sudah disimaknya dan 
dibacanya. Dalam kegiatan diskusi ketua kelompok menguraikan secara singkat ide-ide yang sudah dipahami kepada anggota kelompok untuk mengingatkan kembali materi yang sudah disimak atau dibacanya. Diskusi yang dilaksanakan, dosen model menemukan beberapa mahsiswa yang aktif, masiswa yang pasif, bahkan mahasiswa yang antusias dalam mengikuti diskusi. Untuk beberapa kelompok sangat aktif dan antusias, bahkan saling bekerjasama dalam membuat pertanyaan/soal yang berkaitan dengan materi terutama pada kelompok 4, bahkan saling berbagi pengetahuan antaranggota dalam kelompok. Sementara pada kelompok lain yakni kelompok 1, ada mahasiswa yang bernama $\mathrm{B}$ belum termotivasi secara penuh dalam membahas materi terutama dalam pembuatan pertanyaan/soal; kelompok 2 juga belum maksimal dalam mengikuti diskusi terutama mahasiswa yang bernama $\mathrm{F}$; untuk kelompok 3, mahsiswa yang bernama Lilik sudah berminat untuk mengikuti diskusi kelompok, tetapi kegiatan diskusi tersebut beralih memperhatikan kelompok lain; sedangkan kelompok 5 sangat aktif dalam melaksanakan diskusi tertuma dalam pembuatan pertanyaan/soal.

Dalam kegiatan diskusi, dosen tetap melakukan pengamatan terhadap mahasiswa dalam kelompok untuk mengetahui kemampuan mahasiswa dalam memahami dan menguasai materi yang didiskusikan. Dosen memberi arahan dan bimbingan kepada mahasiswa yang terlihat kurang aktif dalam diskusi supaya mahasiswa tersebut berminat dan termotivasi dalam mengikuti diskusi. Diskusi yang dilakukan, mahasiswa diminta untuk membuat/menulis pertanyaan/soal sesuai dengan materi yang dijelaskan dan dikembangkan. Dosen memberi kesempatan kepada anggota kelompok untuk mempersiapkan jawaban dari pertanyaan yang dibuat. Dosen membimbing dan mengarahkan mahasiswa untuk menguasai konsep materi yang dibahas supaya mampu membuat jawaban atas pertanyaan yang dibuat. Dari diskusi terlihat, bagaimana mahasiswa belajar (untuk mendapatkan haknya sebagai mahasiswa) dan bekerjasama untuk mendapatkan pengetahuan/konsep teori yang didiskusikan. Melalui kegiatan diskusi dalam pembelajaran yang lakukan akan membentuk cara belaj ar yang lebih baik lagi, mulai dari penguasan materi, keaktifan, dan kerja sama dalam kelompok, serta mampu menanggapi dan mengomunikasikan yang sudah didapat melalui proses pem dengan melakukan pembelajaran.

\section{D). Kegiatan Presentasi}

Setelah pembuatan pertanyaan/soal dan mempersiapkan jawaban atas pertanyaan yang dibuat, maka langkah selanjutnya adalah mempresentasikan hasil diskusi melalui tanya jawab. Pertanyaan yang dibuat dalam gulungan kertas sehingga berbentuk bola 
yang kemudian dilemparkan kepada diberikan kelompok 2 dan kelompok 4. kelompok lain untuk menjawab pertanyaan Berikutnya beralih pada kelompok 5 yang yang dibuat melalui masing-masing melemparkan gulungan kertas berbentuk bola kelompok. Kelompok yang mendapatkan gulungan bola dari kelompok lain yang berisi pertanyaan/soal, maka kelompok tersebut secara bergiliran akan menjawab pertanyaan tersebut. Apabila ada kelompok yang belum mampu menjawab secara maksimal sesuai dengan pertanyaan yang diberikan oleh kelompok lain, maka kesempatan ini akan diberikan kepada kelompok lainnya lagi. Jadi mahasiswa bukan hanya belajar melalui anggota dalam kelompok, tetapi memberi kesempatan kepada kelompok lain untuk berbagi pengetahuan yang sudah didiskusikan melalui kelompok. Kegiatan presentasi yang dilakukan oleh masing-masing kelompok terlihat saat dosen menunjuk salah satu kelompok yakni kelompok 2 (kelompok Febrianti) melemparkan bola yang berisi pertanyaan/soal kepada kelompok 4 (kelompok C) maka kelompok 4 akan menjawab pertanyaan nomor satu dari lima pertanyaan yang diberikan oleh kelompok 2, kemudian kelompok 4 (kelompok C) akan melemparkan gulungan kertas berbentuk bola kepada kelompok 5 (kelompok D) untuk menjawab pertanyaan nomor satu yang diberikan oleh kelompok 4 (kelompok C), kemudian dosen tetap memberi kesempatan kepada kelompok lain yakni kelompok 1 dan 3 untuk menanggapi ataupun menambahkan jawaban sesuai dengan pertanyaan yang pada kelompok 3, kelompok 3 pun membuka gulungan kertas berbentuk bola, berusaha untuk menjawab pertanyaan yang diberikan oleh kelompok 5, kelompok 4 pun membantu kelompok 3 untuk menjawab pertanyaan yang dikemukakan oleh kelompok 5.

Dari kegiatan tanya jawab dalam diskusi ini dilakukan dari kelompok yang satu beralih pada kelompok lain untuk bekerja sama dalam mengomunikasikan pengetahuan yang diperolehnya. Begitu seterusnya bola kertas yang berisi pertanyaan dijawab secara berurutan sampai nomor lima oleh masingmasing kelompok dan masing-masing kelompok saling menanggapi atas pertanyaan dan jawaban yang dikemukan oleh anggota dalam kelompok. Dari kegiatan presentasi terlihat adanya kerjasama antarkelompok maupun kelompok ke kelompok lainnya. Hak belajar mahasiswa terlihat pada saat mahasiswa mengemukakan pendapat mengenai jawaban yang sedikit ada perbedaan, tetapi tetap memiliki persamaan dengan jawaban yang dikemukakan oleh kelompok sebelumnya. Hak belajar selanjutnya, mahasiswa tetap diberi kesempatan untuk bertanya maupun menanggapi terkait pertanyaan dan jawaban yang dikomunikasikan. Sementara hak dosen adalah mengarahkan dan membimbing 
mahasiswa dalam mengomunikasikan apa yang sudah didiskusikan.

\section{E). Kegiatan Menyimpulkan}

Dalam kegiatan dosen model memberi kesempatan pada mahasiswa untuk menyimulkan isi materi yang sudah dibaca, didengar, didiskusikan, dan dipresentasikan materi pengembangan sikap kritis dalam membaca. Kegiatan penyimpulan isi materi diawali oleh kelompok 1 yang disimpulkan baru sebagian dari materi yang dibahas, lalu simpulan tersebut ditambahkan oleh kelompok 5, sehingga inti dari materi yang didiskusikan bisa diketahui sub-sub dari materi yang dibahas. Kegiatan penyimpulan yang dikomunikasikan oleh mahasiswa disempurnakan, sehingga mahasiswa mampu menemukan dan menguasai konsep materi yang dibahas terkait dengan pengembangan sikap kritis dalam membaca.Hak belajar terlihat ketika dosen memberi kesempatan kepada mahasiswa untuk mengomunikasi/menyimpulkan hasil dari materi yang sudah didiskusikan dan dosen model menyempurnakan atau menambahkan simpulan yang dikomunikasikan oleh mahasiswa.

\section{Refleksi (See)}

Kegiatan refleksi dilakukan setelah kegiatan pembelajaran (do) selesai dilaksanakan, dosen model dan obsever melakukan sharing guna atas temuannya. Dosen model dipandu oleh moderator dalam mengemukakan temuannya terkait dengan pembelajaran mata kuliah keterampilan membaca. Temuannya, ada bebeapa mahasiswa dalam kelompok yang tidak aktif dalam mengikuti diskusi, sementara kelompok lain ada yang aktif, bahkan sangant antusias mengikuti diskusi kelompok. Observer mengemukakan temuannya yang hampir sama juga dengan yang dikemukakan oleh observer, temuan ada beberapa mahasiswa saat diskusi menatap cameramen cukup lama, lalu melakukan diskusi lagi, kelompok lain ada yang diam dan tidak mengemukakan pendapat sedikitpun, tetapi ada juga anggota kelompok mengajari temanya yang tidak mengerti, bahkan saling bekerjasama untuk menemukan konsep materi.Melalui temun ini dosen model akan memperbaiki kinerja mengajarnya untuk menjadi lebih baik lagi.

\section{PENUTUP}

Komunitas belajar mata kuliah keterampilan membaca bersifat demokratis dan terbuka, artinya dalam proses pembelajaran, mahasiswa belajar untuk berbagi pengetahuan dengan anggota kelompok dan saling bekerjasama untuk memperoleh pengetahuan/konsep teori yang didiskusikan dalam kelompok, dan berbagi pengetahuan dengan kelompok lain. Dalam 
diskusi yang dilaksanakan oleh mahasiswa semester III terliahat adanya kerjasama antaranggota dalam kelompok maupun kelompok dengan kelompok lain,begitu pula dengan dosen model juga memberi kesempatan kepada mahasiswa untuk bertanya ataupun menangapi terkait dengan materi yang didiskusikan dalam kelompok.. Bersifat terbuka terlihat dalam proses pembelajaran, dosen model membuka kelasnya untuk diamati oleh dosen lain di luar program studi yakni Program Studi Pendidikan Matematika. Bersifat tindak lanjut maksudnya dosen model melakukan perbaikan pembelajaran sesuai dengan saran yang dikemukakan oleh para observer.

\section{DAFTAR PUSTAKA}

Hendayana, dkk. 2007. Lesson Study Suatu Strategi Untuk Meningkatakan Keprofesionalan Pendidik (Pengalaman IMSTEP-JICA). Bandung: UPI Press. http//akhmadsudrajad.wordpress com/2008/02/22/lesson study-untuk meningkatkan-pembelajaran.
Makalah Lesson Study disampaikan dalam Pelatihan Pengembangan Keterampilan Teknik Instruksional (PEKERTI). Universitas Muhammadiyah Metro selama 4-8 Januari 2017.

Rusman.2010. Model-Model Pembelajaran Mengembangkan Profesional Guru. Bandung: Raja Grafinda Persada.

Sukirman.2006.Peningkatan Profesional Guru Melalui Lesson Study. Makalah disampaikan pada kegiatan Pelatihan 2 Hari untuk Fasilitator dan Tim TPK SISTTEM Bantul Emergency Program, 11-12 Agustus 2016.

Slamet, Subad, T, Sutama, \& Khotimah,R.P.2010. Peningkatan Kompetensi Guru Sekolah Dasar Melalui Lesson Study. Jurnal Warta, Vol .13, No.1, 55-64.

Susilo, H,dkk. 2009. Lesson Study Berbasis Sekolah. Malang: Bayumedia Publising.

Tri Priyatni Endah.2014. Desain Pembelajaran Bahasa Indonesia dalam Kurikulum 2013. Cahaya Prima Sentosa: Jakarta. 